\title{
Penerapan Model Pembelajaran Course Review Horay (CRH) untuk Meningkatkan Aktivitas dan Hasil Belajar Peserta Didik pada Mata Pelajaran Matematika di SDN 1 Gununglipung
}

\author{
Fahmi Fikri Fauzi, Cece Rakhmat, Hatma Heris Mahendra \\ Universitas Perjuangan Tasikmalaya \\ fahmifikrifauzi1515@gmail.com
}

\section{Article History}

accepted 2/11/2019

approved 23/11/2019

published 31/12/2019

\begin{abstract}
This research was motivated by the low activity and students learning outcomes on mathematics subject. The purpose of this study was to describe the activities and students learning outcomes in the application of Course Review Horay (CRH) learning model and improving students learning by applying the Course Review Horay $(C R H)$ learning model in mathematics subject. The method used in this research was classroom action research that adapted from Kemmis and Taggart models. The subjects of this research were fifth grade on SDN 1 Gununglipung, Cipedes, Tasikmalaya with 35 students. Data collection was done through tests and observation sheets of learning activities of students. The results showed in the pre-cycle stage of classical learning completeness reached $20.7 \%$ with the percentage of learning activities $44 \%$. Then in cycle I classical learning completeness reached $41.4 \%$ with the percentage of learning activities $61 \%$. Then, in cycle II the classical learning completeness reached $75 \%$ with the percentage of learning activitie $77 \%$. This showed an increase from the pre-cycle stage to the cycle II. Based on the results of this research, it can be concluded that the application of the learning model of Course Review Horay $(\mathrm{CRH})$ on mathematics subject can improve the activities and students learning outcomes.
\end{abstract}

Keywords: Activity, Learning Outcomes, CRH

\begin{abstract}
Abstrak
Penelitian ini dilatar belakangi oleh rendahnya aktivitas dan hasil belajar peserta didik pada mata pelajaran matematika. Tujuan penelitian ini adalah untuk mendeskripsikan peingkatan aktivitas dan hasil belajar peserta didik dalam penerapan model pembelajaran Course Review Horay $(\mathrm{CRH})$. Metode yang digunakan dalam penelitian ini adalah Penelitian Tindakan Kelas yang mengadaptasi model Kemmis dan Taggart. Subjek penelitian ini adalah peserta didik Kelas V SDN 1 Gununglipung Kota Tasikmalaya sebanyak 35 orang. Pengumpulan data dilakukan melalui tes dan observasi aktivitas belajar peserta didik. Hasil penelitian menunjukan tahap Pra Siklus ketuntasan belajar klasikal mencapai 20,7\% dengan persentase aktivitas belajar sebesar 44\%. Sementara pada Siklus I ketuntasan belajar klasikal mencapai 41,4\% dengan persentase aktivitas belajar sebesar 61\%. Dan pada Siklus II ketuntasan belajar klasikal mencapai 75\% dengan persentase aktivitas belajar sebesar 77\%. Berdasarkan hasil penelitian tersebut, dapat disimpulkan penerapan model pembelajaran Course Review Horay $(\mathrm{CRH})$ pada mata pelajaran matematika dapat meningkatkan aktivitas dan hasil belajar peserta didik.
\end{abstract}

Kata kunci: Aktivitas, Hasil Belajar, CRH

Social, Humanities, and Education Studies (SHEs): Conference Series https://jurnal.uns.ac.id/shes

p-ISSN 2620-9284 e-ISSN 2620-9292 


\section{PENDAHULUAN}

Menurut Rogers dalam Mahendra dan Febriani (2019:8) belajar dapat membantu peserta didik untuk mengidentifikasi dan menemukan perwujudan dari dirinya atau biasa dikenal dengan self realization yang disesuaikan dengan keunikan dan kemampuan dasar yang dimiliki oleh peserta didik. Proses pembelajaran sangat tergantung dari bagaimana pendidik mampu menjadi fasilitator, koordinator, mediator yang memudahkan peserta didik mencapai tujuan pembelajaran. Permasalahan yang dibahas dalam penelitian ini adalah masih rendahnya aktivitas dan hasil belajar peserta didik pada pembelajaran matematika di sekolah dasar. Keberhasilan belajar peserta didik salah satunya dipengaruhi oleh faktor guru. Di mana guru sebagai salah satu personal dalam sekolah berperan penting untuk pencapaian keberhasilan tersebut. Kemampuan guru dalam mengajar harus benar-benar diperhatikan. Sebab kualitas peserta didik akan ditentukan oleh baik dan buruknya proses pembelajaran yang dilakukan oleh guru. Proses pembelajaran yang baik akan selalu melibatkan peserta didik secara aktif dalam setiap kegiatan pembelajaran sehingga dapat meningkatkan ativitas peserta didik, yang pada akhirnya peserta didik akan memperoleh hasil belajar yang optimal.

Berdasarkan hasil wawancara dengan guru kelas, data diperoleh bahwa rendahnya aktivitas dan hasil belajar peserta didik dalam pembelajaran matematika disebabkan oleh beberapa faktor, diantaranya: banyak siswa memandang pelajaran matematika sebagai pelajaran yang kurang menarik dan pelajaran yang paling sulit. Sehingga minat dan motivasi belajar peserta didik dalam mata pelajaran matematika sangat kurang; dan kesempatan bertanya yang diberikan guru kerap kali tidak dipergunakan dengan baik, peserta didik hanya berdiam diri saja sementara mereka belum memahami materi yang disampaikan guru. Akibatnya hasil belajar sebagian besar peserta didik pada mata pelajaran Matematika belum mencapai Kriteria Ketuntasan Minimal (KKM) yang ditentukan sekolah yaitu $\geq 75$.

Upaya dalam mengatasi permasalahan tersebut dilakukan dengan diterapkannya pembelajaran Course Review Horay $(\mathrm{CRH})$. Model pembelajaran $\mathrm{CRH}$ ini dapat menciptakan suasana kelas yang meriah dan menyenangkan sehingga dapat meningkatkan aktivitas peserta didik dalam belajar serta dapat meningkatkan hasil belajar yang dicapai peserta didik setelah mengikuti pelajaran.

Berdasarkan latar belakang di atas, maka rumusan masalah dalam penelitian ini adalah bagaimana aktivitas dan hasil belajar peserta didik dalam penerapan model pembelajaran Course Review Horay (CRH) pada pembelajaran matematika, serta apakah dengan penerapan model pembelajaran Course Review Horay (CRH) dapat meningkatkan aktivitas dan hasil belajar peserta didik pada pembelajaran matematika di SDN 1 Gununglipung?.

Sesuai dengan rumusan masalah yang telah diuraikan diatas, tujuan yang ingin dicapai dalam penelitian ini adalah untuk mendeskripsikan dan meningkatkan ativitas dan hasil belajar peserta didik dalam penerapan model pembelajaran Course Review Horay $(\mathrm{CRH})$ pada pembelajaran matematika di SDN 1 Gununglipung.

Course Review Horay merupakan model pembelajaran yang dapat menciptakan suasana kelas menjadi meriah dan menyenangkan karena setiap peserta 
didik yang dapat menjawab benar diwajibkan berteriak 'horee!!' atau yel-yel lainnya yang disukai. Model ini berusaha menguji pemahaman peserta didik dalam menjawab soal, dimana jawaban soal tersebut dituliskan pada kartu atau kotak yang telah dilengkapi nomor. Peserta didik atau kelompok yang memberikan jawaban benar harus langsung berteriak 'horee!!' atau menyanyikan yel-yel kelompoknya (Huda, 2014: 229 230).

Aktivitas belajar merupakan kegiatan yang melibatkan kegiatan fisik dan pikiran dalam bentuk partisipasi, minat, perhatian, dan presentasi pembelajaran melalui pengalaman sendiri untuk memperoleh informasi atau pengetahuan baru, sehingga mengakibatkan perubahan tingkah laku peserta didik yang dilakukan dalam proses interaksi (guru dan peserta didik) dalam rangka mencapai tujuan belajar. Aktivitas belajar banyak macamnya. Paul D. Dierich (Hamalik, 2016: 172) membagi aktivitas belajar menjadi 8 kelompok, yaitu: aktivitas visual, lisan, mendengarkan, menulis, menggambar, metrik, mental, dan emosional.

Menurut Susanto (2015: 5) menyatakan bahwa "Hasil belajar merupakan perubahan-perubahan yang terjadi pada diri peserta didik, baik yang menyangkut aspek kognitif, afektif, dan psikomotor sebagai hasil dari kegiatan belajar". Bloom (Tampubolon, 2014: 140) secara garis besar membagi hasil belajar menjadi tiga ranah, yaitu ranah kognitif, ranah afektif, dan ranah psikomotor.

\section{METODE}

Metode yang digunakan dalam penelitian ini adalah Penelitian Tindakan Kelas (PTK) dengan menggunakan desain atau model Kemmis dan Taggart. Penelitian dilaksanakan di SDN 1 Gununglipung yang beralamatkan di Jalan Ampera Desa Panglayungan Kecamatan Cipedes Kota Tasikmalaya. Subjek yang ditetapkan dalam penelitian ini adalah peserta didik Kelas V SDN 1 Gununglipung sebanyak 35 orang. Pada penelitian ini teknik pengumpulan data yang digunakan adalah teknik tes dan nontes. Teknik tes digunakan untuk mengukur hasil belajar peserta didik berupa soal pilihan ganda. Sedangkan teknik non tes berupa observasi dan dokumentasi. Teknik yang digunakan untuk menganalisis data adalah dengan analisis data kuantitatif secara sederhana, yaitu dengan menghitung jumlah atau menggunakan persentase. Adapun teknik analisis data untuk masing-masing data dalam penelitian ini adalah sebagai berikut:

1) Analisis Data Observasi

Rumus untuk menentukan persentase aktivitas belajar peserta didik yaitu sebagai berikut.

$$
\text { Persentase }=\frac{\text { Skor keseluruhan yang diperoleh }}{\text { Skor maksimal }} \times 100 \%
$$

2) Analisis Data Hasil Belajar Peserta Didik

Rumus untuk mencari nilai akhir hasil belajar, NA= Jumlah yg benar $\times b$

Rumus untuk mencari rata-rata nilai, $\bar{x}=\frac{\sum x i}{n}$

Rumus untuk mencari persentase ketuntasan belajar klasikal, $P=\frac{N t}{N} \times 100 \%$ 


\section{HASIL DAN PEMBAHASAN}

Hasil aktivitas belajar peserta didik diperoleh dari hasil pengamatan pada saat kegiatan pembelajaran berlangsung dan hasil belajar peserta didik diperoleh melalui pemberian soal evaluasi di setiap akhir pembelajaran. Pada tahap Pra Siklus diperoleh data keaktifan peserta didik dalam pembelajaran Pra Siklus ini mencapai 44\%. Dalam kriteria yang dibuat Yonny dkk, maka keaktifan peserta didik di kelas $\mathrm{V}$ termasuk kasifikasi "Sedang". Sedangkan, untuk hasil belajar peserta didik diperoleh data bahwa pada tahap Pra Siklus hanya ada 6 peserta didik (20,7\%) yang telah mencapai batas tuntas dengan memperoleh nilai $\geq 75$. Sedangkan sisanya, sebanyak 23 peserta didik $(79,3 \%)$ masih belum mencapat KKM yang ditentukan dengan memperoleh nilai $<75$ dengan rata-rata nilai 50,3 .

Pada Siklus I terbukti adanya peningkatan kegiatan belajar peserta didik jika dibandingkan dengan aktivitas belajar pada tahap Pra Siklus yang pada Siklus I ini mencapai rata-rata $61 \%$. Sesuai dengan kriteria yang dibuat Yonny dkk, maka keaktifan peserta didik di kelas $V$ termasuk kasifikasi "Tinggi". Pada Siklus ini juga hasil belajar mengalamai peningkatan dimana sebanyak 12 peserta didik $(41,4 \%)$ tuntas belajar dan sebanyak 17 peserta didik (58,6\%) lainnya masih belum mencapai KKM yang sudah ditentukan dengan rata-rata 69,3.

Pada Siklus II, aktivitas dan hasil belajar peserta didik kembali mengalami peningkatan. Pada Siklus II ini aktivitas belajar mencapai taraf keberhasilan persentase rata-rata $77 \%$. Sesuai dengan kriteria yang dibuat Yonny dkk, maka keaktifan peserta didik di kelas $\mathrm{V}$ termasuk kasifikasi "Sangat Tinggi". Dan untuk hasil belajarnya diketahui rata-rata kelas telah mencapai 78,6 dengan 21 peserta didik (75\%) tuntas belajar dan sebanyak 7 peserta didik (25\%) lainnya masih belum mencapai KKM yang sudah ditentukan dengan rata-rata perolehan 78,6.

Peningkatan rata-rata nilai hasil belajar peserta didik dan persentase ketuntasan belajar dari Pra Siklus ke Siklus II dapat digambarkan pada diagram dibawah ini: 
SHEs: Conference Series 2 (2) (2019) $110-115$

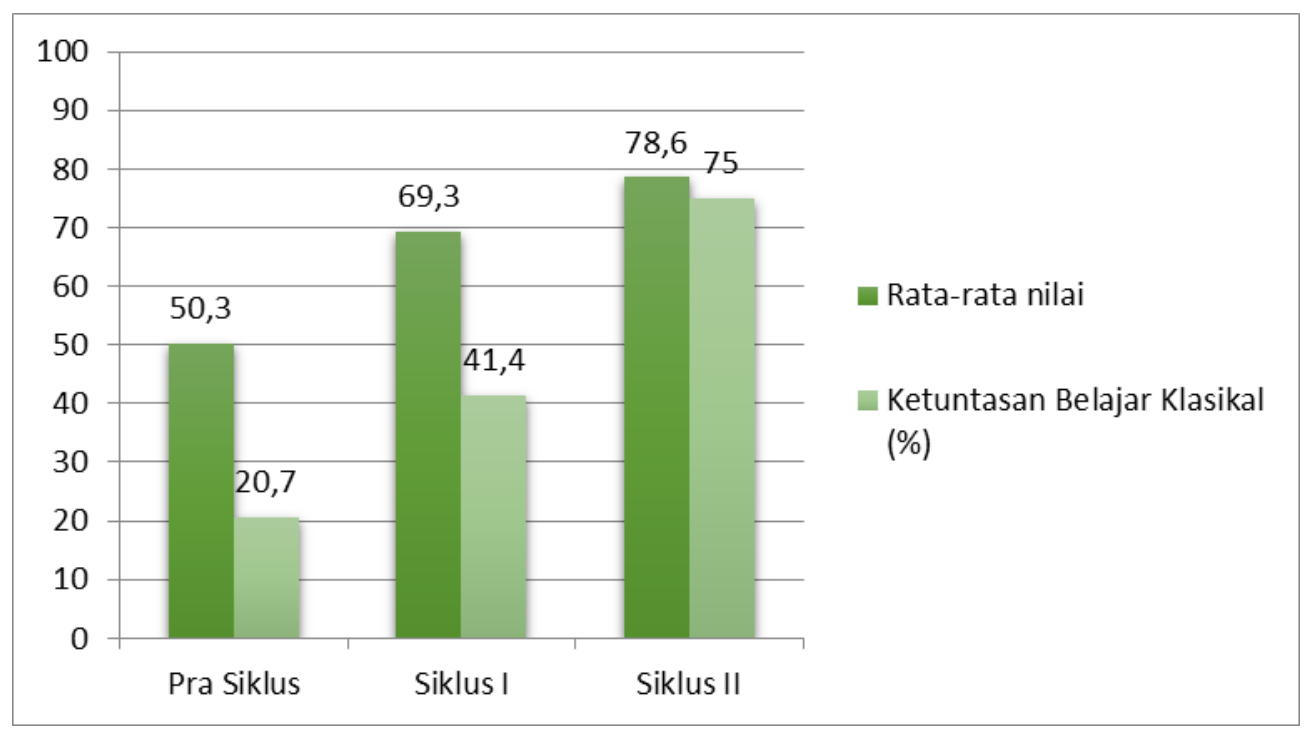

Gambar 1. Diagram Peningkatan Hasil Belajar Peserta Didik

Dari diagram 1, dapat diketahui bahwa sebelum diberi tindakan diperoleh hasil belajar peserta didik yang mencapai nilai $<75$ sebanyak 23 orang $(79,3 \%)$ dan $>75$ hanya sebanyak 6 orang $(20,7 \%)$ dengan nilai rata-rata 50,3. Pada post test Siklus I, nilai rata-rata meningkat menjadi 69,3 dengan jumlah peserta didik yang tuntas sebanyak 12 orang $(41,4 \%)$ dan sisanya sebanyak 17 orang $(58,6 \%)$ masih belum mencapai nilai KKM. Dan pada Siklus II, nilai rata-rata sudah mencapai indikator keberhasilan penelitian yaitu harus mendapat rata-rata $\geq 75$ dengan capaian akhir nilai rata-rata meningkat menjadi 78,6 dengan jumlah peserta didik yang tuntas sebanyak 21 orang $(75 \%)$ dan sisanya sebanyak 7 orang (25\%). Dengan demikian, dapat dikatakan bahwa model pembelajaran Course Review Horay mampu meningkatkan aktivitas dan hasil belajar peserta didik kelas V SDN 1 Gununglipung.

\section{SIMPULAN}

Berdasarkan penelitian yang telah dilakukan, dapat ditarik beberapa kesimpulan sebagai berikut:

1. Melalui penerapan model pembelajaran Course Review Horay, pembelajaran di kelas tidak lagi berpusat pada guru melainkan lebih menekankan pada keaktifan dari peserta didik. Sebelum diberi tindakan, perolehan persentase rata-rata aktivitas belajar peserta didik kelas V SDN 1 Gununglipung hanya mencapai 44\%. Setelah diberikan tindakan pada Siklus I, ternyata persentase rata-rata aktivitas belajar peserta didik meningkat menjadi $61 \%$ dan terus meningkat pada Siklus II dengan capaian persentase rata-rata $77 \%$. Berdasarkan kriteria ketuntasan yang telah ditetapkan di awal, berarti pada Siklus II ini aktivitas belajar peserta didik telah memenuhi atau telah tercapai dengan kriteria "Sangat Tinggi".

2. Meningkatnya persentase aktivitas peserta didik dalam belajar ternyata berpengaruh atau berdampak positif terhadap meningkatnya hasil belajar peserta didik. Sebelum diberi tindakan diperoleh hasil belajar peserta didik yang mencapai nilai $<75$ sebanyak 23 orang $(79,3 \%)$ dan $>75$ hanya sebanyak 6 orang $(20,7 \%)$ dengan nilai rata-rata 50,3. Pada post test Siklus I, nilai rata-rata meningkat menjadi 69,3 dengan jumlah peserta didik yang tuntas sebanyak 12 orang $(41,4 \%)$ dan sisanya sebanyak 17 orang $(58,6 \%)$ masih belum mencapai nilai KKM. Dan 
4th National Seminar on Guidance and Counseling (SNBK 2019) and Workshop on

Pedagogical Theory and Practice (WTPP 2019)

SHEs: Conference Series 2 (2) (2019) 110 - 115

pada Siklus II, nilai rata-rata sudah mencapai indikator keberhasilan penelitian yaitu harus mendapat rata-rata $\geq 75$ dengan capaian akhir nilai rata-rata meningkat menjadi 78,6 dengan jumlah peserta didik yang tuntas sebanyak 21 orang (75\%) dan sisanya sebanyak 7 orang (25\%) masih belum mencapai nilai KKM. Dengan demikian, model pembelajaran Course Review Horay terbukti dapat meningkatkan aktivitas dan hasil belajar peserta didik pada mata pelajaran Matematika dalam materi menjumlahkan dan mengurangkan berbagai bentuk pecahan di kelas V SDN 1 Gununglipung.

\section{DAFTAR PUSTAKA}

Al-Tabany, T.I.B. (2014). Mendesain Model Pembelajaran Inovatif, Progresif, dan Kontekstual: Konsep, Landasan, dan Implementasinya pada Kurikulum 2013. Jakarta: Prenadamedia Group.

Hamalik, O. 2016. Proses Belajar Mengajar. Jakarta: PT Bumi Aksara.

Huda, M. 2014. Model-Model Pengajaran dan Pembelajaran. Yogyakarta: Pustaka Pelajar.

Indrawati, R.M. 2013. Peningkatan Aktivitas dan Hasil Belajar Materi Peristiwa Sekitar Proklamasi Melalui Bermain Peran. Journal of Elementary Education Universitas Negeri Semarang, ISSN 2252-9047.

Mahendra, Hatma Heris \& Winarti Dwi Febriani. (2019). Pembelajaran Berbasis Pendidikan Humanistik Pada Mata Pelajaran Ips Di Sekolah Dasar. Jurnal Tunas Bangsa, Vol. 6, No.1, Februari 2019

Rusman. (2016). Model-Model Pembelajaran: Mengembangkan Profesionalisme Guru. Jakarta: Rajawali Pers.

Sani, R.A. dan Sudiran. 2016. Penelitian Tindakan Kelas: Pengembangan Profesi Guru. Tangerang: Tsmart.

Shoimin, A. (2014). 68 Model Pembelajaran Inovatif dalam Kurikulum 2013. Yogyakarta: Ar-Ruzz Media.

Susanto, A. 2015. Teori Belajar dan Pembelajaran di Sekolah Dasar. Jakarta: Prenada Media.

Tampubolon, S. 2014. Penelitan Tindakan Kelas Sebagai Pengembangan Profesi Pendidikan dan Keilmuan. : Bandung: Erlangga

Taniredja, T. et al. (2015). Model-Model Pembelajaran Inovatif dan Efektif. Bandung: Alfabeta. 